7.4.

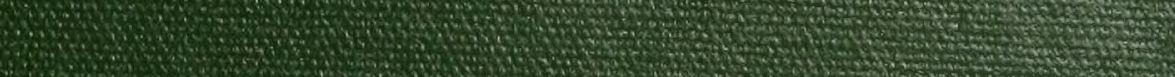
Hing 


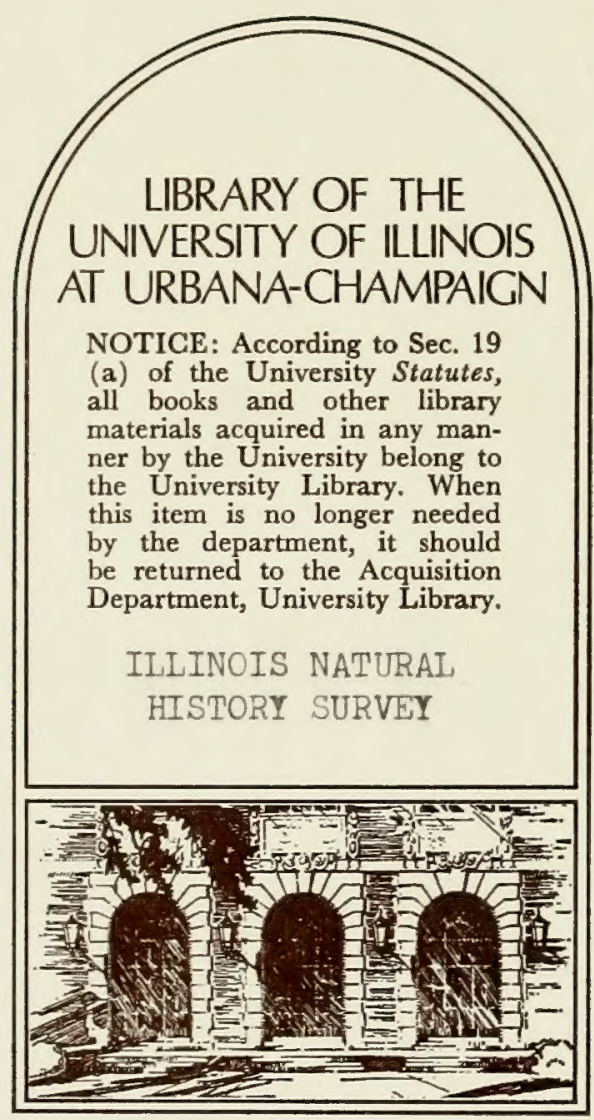








\section{A Bibliography}

of the Northern Corn Rootworm

and the Western Corn Rootworm:

\section{An Updating through 1976}

Bonnie J. Irwin

STATE OF ILLINOIS

Department of Registration and Education

Natural History Survey Division 
The CONTINUING RESEARCH and publication of articles on the northern corn rootworm, Diabrotica longicornis (Say), and the western corn rootworm, $D$. virgifera LeConte, have prompted this updating of Illinois Natural History Survey Biological Notes No. 90. Current works are included as well as older articles that have been located since the April 1974 publication of the original bibliography.

Except for those few citations preceded by the symbol \#, reprints or copies were obtained of each paper. These are on file at SIRIC (Soybean Insect Research Information Center, 163 Natural Resources Building, Urbana). The contents of all articles have been coded for entry into the SIRIC system, as northern and western corn rootworm adults readily invade fields of soybeans and feed on the foliage. SIRIC is a computerized information storage and retrieval system which deals with the literature on arthropods associated with soybeans.

A "Listing of References by Rootworm Species" and a list of periodical abbreviations have again been included.

The collaboration of these people is gratefully acknowledged: Kathy Wood for general assistance and proofreading, Mary Rose for typing, and R. M. Zewadski, editor, Illinois Natural History Survey, for editing.

This bibliography is a contribution of the Illinois Natural History Survey and the Illinois Agricultural Experiment Station in cooperation with a multistate USEPA project, "Bionomics and Management of Soil Arthropod Pests 802547-5." Cooperating institutions and state investigators in this project are:

Missouri - M. L. Fairchild, Principal Investigator, USEPA Soil Arthropod Project

\section{A. J. Keaster}

Indiana -E. E. Ortman, Coordinator Corn Soil Insects subproject

F. T. Turpin

IlLiNoIS -W. H. Luckmann

Iowa -Jon Tollefson

Nebraska-Z. B. Mayo

OHIO

$$
\text { -R. W. Rings }
$$
This paper is published by authority of the State of Illinois, IRS Ch.
127. Par, 58.12, and is a contribution from the Section of Economic En127, Par, 58.12, and is a contribution from the Section of Economic En-
tomology of the Illinois Natural History Survey, where B. Irwin is a Research Assistant.

\section{BIBLIOGRAPHY}

\#1. Ajani, A., and J. H. Lonnquist. 1976. Biological resistance to corn rootworm. Can. J. Plant Sci. $56(2)$ : 429.

2. Allen, W. A. 1975. The biology and distribution of the northern corn rootworm (Diabrotica longicornis) -a new pest in Virginia. Va. J. Sci. $26(2): 40$. Refs.

3. Alvarez, C. G. 1975 . Corn rootworm control with Counter. Proc. N. Cent. Br. Entomol. Soc. Amer. $30: 82$.

4. Anonymous. 1975. The rootworm. Agrichem. Age 18 (5) :8-9. Illus.

5. Apple, J. W. 1949. What is new in the control of insect enemies of corn. Proc. Annu. Hybrid Corn Ind. Res. Conf. 4:45-57. Refs.

6.

1971. Response of corn to granular insecticides applied to the row at planting. J. Econ. Entomol. 64 (5) : 1208-1211. Illus.

7. Arizona Agricultural Experiment Station. 1971. Insect control in field corn, sorghum, and small grains 1971-72. Ariz. Agr. Exp. Sta. Ariz. Coop. Ext. Serv. Folder 146. 5 p.

8. Armenta, S. C. 1974. Population fluctuations of certain soybean pests and their control in the Fuerte Valley, Sinaloa, Mexico. Folia Entomol. Mex. 29:65-66.

9. Arnold, E. W., and J. W. Apple. 1960. Survey to estimate soil insect damage to corn. Proc. N. Cent. Br. Entomol. Soc. Amer. 15:81-83. Illus. Refs.

10. BalL, H. J. 1956. Effect of insecticides to corn root growth. J. Econ. Entomol. 49 (2) :230-233. Illus. Refs.

11. C. A. Staetz, and G. L. Rolofson. 1975. $\overrightarrow{\text { Negative }}$ phototactic activity used to determine larval toxicity of insecticides to Diabrotica virgifera. J. Econ. Entomol. 68 (3) :293-294. Illus. Refs.

12. Barre, H. W., and A. F. Conradi. 1909. Treatment of plant diseases and injurious insects in South Carolina. S. C. Agr. Exp. Sta. Bull. 141. 52 p.

13. Barrett, J. R., F. W. Harwood, and H. O. Deay. 1972. Functional association of light trap catches to emission of blacklight fluorescent lamps. Environ. Entomol. 1 (3) :285-290. Illus. Refs.

14. Berry, P. A., and M. Salazar Vaquero. 1957. Lista de insectos clasificados de El Salvador (List of classified insects of El Salvador). El Salvador Min. Agr. Ganad. Bol. Tec. 21. 134 p.

15. Blair, B. D., G. J. Musick, W. F. Lyon, R. E. Treece, D. L. Goleman, and A. C. Waldron. 1970. Suggested guide for the use of insecticides to control insects affecting field corn, small grains and soybeans. Ohio Coop. Ext. Serv. Bull. 495. 8 p.

16. Blatchley, W. S. 1910. An illustrated descriptive catalogue of the Coleoptera or beetles (exclusive of the Rhynchophora) known to occur in Indiana. Indiana Dep. Geol. Natur. Res. Bull. 1. 1386 p. (see p. 1172) Illus. Maps. 
17. Buickenstaff, C. C., and J. L. Huggans. 1962. Soybean insects and related arthropods in Missouri. Mo. Agr. Exp. Sta. Res. Bull. 803. 51 p. Illus. Refs.

18. Bocanegra, S., and J. E. Simon F. 1958. Resultados de un experimento comparativo de insecticidas contra los insectos del maiz para grano (Results of a comparative experiment of insecticides against the insects of grain corn). Rev. Peru. Entomol. Agr. 1 (1):66-69. Illus.

419. BonNEFIL, L. 1973. Goals and means for protecting Phaseolus vulgaris in the tropics. CIAT Ser. Semin. 2c:229-232.

20. Branson, T. F. 1974. Early egg hatch in an unchilled population of western corn rootworms. Proc. N. Cent. Br. Entomol. Soc. Amer, 29:195.

21.

1976. The selection of a non-diapause strain of Diabrotica virgifera (Coleoptera:Chrysomelidae). Entomol. Exp. Appl. 19:148-154. Illus. Refs.

1976. Viability and hatching pattern of eggs of the western corn rootworm exposed to chill periods of different durations. Entomol. Exp. Appl. 19 (1) :77-81. Illus. Refs.

23. P. L. Guss, J. L. Krysan, and G. R. Suttler. 1975. Corn rootworms: Laboratory rearing and manipulation. U. S. Dep. Agr. Agr. Res. Serv. NC 28:117. Illus. Refs.

24. Brown, A. W. A. 1968. Insecticide resistance comes of age. Bull. Entomol. Soc. Amer. $14(1): 3-9$. Illus. Refs.

25. Chagnon, G. 1938. Contribution a l'étude des Coléoptères de la province de Québec (A contribution to the study of the Coleoptera of Quebec Province). Natur. Can. 65:13-23. Illus.

26. Chiang, H. C. 1974. Temperature effects on hatching of eggs of the western corn rootworm, Diabrotica virgifera: Factual and theoretical interpretations. Entomol. Exp. Appl. 17:149-156. Illus. Refs. ther observations on temperature effects on hatching of northern and western corn rootworm eggs. Proc. N. Cent. Br. Entomol. Soc. Amer. 29:138-141. Illus. Refs. W. W. Nelson, and R. Gorder. 1971. Distribution of northern corn rootworm individuals in the soil. Proc. N. Cent. Br. Entomol. Soc. Amer. 26 $(1-2): 89$.

29. M. B. Windels, J. A. Mihm, D. E. Rasmus SEN, and L. K. French. 1975. Methods of mass production of corn rootworm eggs in the laboratory and artificial field infestation techniques. Proc. N. Cent. Br. Entomol. Soc. Amer. 30:37-40. Illus. Refs.

30. Chinarapa, L., ed. 1971. Crop loss assessment methods. FAO manual on the evaluation and prevention of losses by pests, diseases and weeds. Commonwealth Agricultural Bureau, Oxford. One vol. Loose leaf. Illus.

31. Cockerell, T. D. A. 1961, Sunflower insects in California and South Africa. Can. Entomol. 48 (3) :76-79.

32. Craig, W. S., J. L. Huggans, L. L. Peters, and G. W. Thomas, compilers. 1972. 1972 Missouri insect control recommendations for use in 1972 only. Mo. Coop. Ext. Serv. Handb. 153 p. Illus.

33. Dанмs, R. G. 1960. Use of resistant varieties-the ideal way to control insects. Plants Gard. 16 (3) :82-87. Illus.

34. Darlington, W. A., G. F. Ludvik, and R. M. Sacher. 1972. MON-0856: A promising new selective insecticide. J. Econ. Entomol. 65 (1):48-50. Illus. Refs.
35. Davis, J. J., 1947. Insects of Indiana for 1946. Proc. Indiana Acad. Sci. 56:147-153. Illus.

36. 1950. Insects of Indiana for 1950. Proc. Indiana Acad. Sci. 60:178-182.

37. 1956. Insects of Indiana in 1956. Proc. Indiana Acad. Sci. 66:104-107.

38. Daynard, T. B., C. R. Ellis, B. Bolwyn, and R. L. Misener. 1975. Effects of carbofuran on grain yield of corn. Can. J. Plant Sci. 55:637-639. Illus. Refs. Maps.

39. DiскE, F. F. 1975. The role of insects in some diseases of maize. Iowa State J. Res. 49 (4, part 2) :553558. Refs.

40. Esau, K. L., and D. C. Peters, 1975. Carabidae collected in pitfall traps in Iowa cornfields, fencerows, and prairies. Environ. Entomol. $4(3): 509-513$. Illus. Refs.

41. Flores, F. R., and O. F. dell Valles. 1973. Eficacia de cyolane y cytrolane, insecticidas sistémicos en el control del gusano soldado Spodoptera exigua (Hübner) atacando alfalfa en Torreón, Coah. (Efficiency of cyolane and cytrolane, systemic insecticides in the control of Spodoptera exigua (Hübner) attacking alfalfa in Torreón, Coah.). Folia Entomol. Mex. 25-26:62-63.

42. Footr, W. H. 1975. Effects of granular systemic insecticides on populations of the corn leaf aphid and yields of field corn in southwestern Ontario. Proc. Entomol. Soc. Ont. 1974. 105:75-79. Illus. Refs.

43. Forbes, S. A. 1904. The more important insect injuries to Indian corn. Ill. Agr. Exp. Sta. Bull. 95:329 399. Illus. Refs. Maps.

44. and C. A. HART. 1900. The economic entomology of the sugar beet. Ill. Agr. Exp. Sta. Bull. 60: 397-532. Illus. Refs.

45. Fulton, J. P., H. A. Scott, and R. GÁmez. 1975. Beetle transmission of legume viruses. Pages 123-131 in J. Bird and K. Maramorosch, eds., Tropical diseases of legumes. Academic Press, N. Y. Illus. Refs.

\#46. GAMEZ, R. 1973. Goals and means for protecting Phaseolus vulgaris in the tropics. CIAT Ser. Semin. 2c:233-236.

47. Garman, H. 1897. Notes on several tobacco insects and on two imperfectly known diseases of tobacco. Ky. Agr. Exp. Sta. Bull. 66:33-39.

48. Goвle, H. W. 1970. Insects of the season 1970 related to fruit, vegetables, field crops and ormamentals. Proc. Entomol. Soc. Ont. 101:7-8.

49. Gould, G. E. 1944. Insect pests of cucurbit crops in Indiana. Proc Indiana Acad. Sci. 53:165-171.

50. GrahaM, L. R., and H. D. TATE. 1944. Corn rootworm. Nebr. Agr. Exp. Sta. Annu. Rep. 1943. 57:5758.

51. Greene, G. L. 1970. Seasonal occurrence of Chrys omelidae in a native prairie near Manhattan, Kansas. J. Kans. Entomol. Soc. 43 (1):95-101. Illus. Refs.

52. Guagliumi, P. 1965. Contributo alla conoscenza dell'entomofauna nociva del Venezuela (Contribution to the knowledge of the injurious insect fauna of Venezuela). Riv. Agr. Subtrop. Trop. 59 (7-9):376-408.

53. 1965. Contributo alla conoscenza dell'entomofauna nociva del Venezuela (continuazione e fine) (Contribution to the knowledge of the injurious insect fauna of Venezuela (continuation and end)) Riv. Agr. Subtrop. Trop. $59(10-12): 447-472$

54. Guibord, M. O. 1976. La chrysoméle des racines du mais, Diabrotica longicornis (Say) (Coléoptères:Chrysomelidae), au Quebec (The northern corn rootworm. 
Diabrotica longicornis (Say) (Coleoptera:Chrysomelidae) in Quebec). Ann. Soc. Entomol. Quebec 21 (1) : 49-51. Illus. Refs.

55. Guss, P. L. 1976. The sex pheromone of the western corn rootworm (Diabrotica virgifera). Environ. Entomol. 5 (2) :219-223. Illus. Refs.

56. — T. F. Branson, and J. L. Krysan, 1974. Developments in large scale rearing of corn rootworms. 2. Adult considerations. Proc. N. Cent. Br. Entomol. Soc. Amer. 29:195-196.

57 and 1976. Adaptation of a dry diet for adults of the western corn rootworm. J. Econ. Entomol. 69 (4) :503-505. Illus. Refs.

58. Gyrisco, G. G., and E. J. Armbrust, 1966. 1966 forage and cereal insect recommendations. N. Y. (Cornell) Coll. Agr. Misc. Bull. 71. 8 p. Illus.

59. Hague, W. 1894. Notes on a few Canadian Coleoptera. Entomol. Soc. Ont. Annu. Rep. 25:47-49.

60. Hendrikson, G. D. 1930. Studies on the insect fauna of Iowa prairies. Iowa State Coll. J. Sci. 4 (2) :49-179. Illus. Refs.

61. Hill, R. E. 1975. Mating, oviposition patterns, fecundity and longevity of the western corn rootworm. J. Econ. Entomol. 68 (3):311-315. Illus. Refs.

62. and Z. B. MAYO. 1974. "Trap corn" as an aid to corn rootworm control. Proc. N. Cent. Br. Entomol. Soc. Amer. 29:194-195.

63. - and 1974. Trap-corn to control corn rootworms. J. Econ. Entomol. 67 (6) :748-750.

64. Hills, T. M., and W. G. Lovely. 1972. Application equipment and techniques used in the evaluation of granular insecticides for control of western corn rootworm Iarvae. J. Econ. Entomol. 65 (4) :1116-1119. Illus.

65. Hopkins, A. D., and W. E. Rumsey. 1896. Practical entomology. W. Va. Agr. Exp. Sta. Bull. 44:245-324. Refs.

66. Howe, W. L., and A. M. Rhodes. 1976. Phytophagous insect associations with Cucurbita in Illinois. Environ. Entomol. 5 (4) :747-751. Illus. Refs

67. $\longrightarrow$ J. R. Sanborn, and A. M. Rhodes. 1976. Western corn rootworm adult and spotted cucumber beetle associations with Cucurbita and Cucurbitacins. Environ. Entomol. 5 (6) :1043-1048. Illus. Refs.

68. Huber, R. T., and J. V. Osmun. 1966. Insects and other arthropods of economic importance in Indiana during 1966. Proc. Indiana Acad. Sci. 76:291-307. Illus.

69. Hughes, J. H. 1944. List of Chrysomelidae (Coleoptera) known to occur in Ohio. Ohio J. Sci. 44 (3): 129-142. Refs.

70. HunteR, W. N. 1891. Injurious insects of Nebraska. Insect Life $4(3-4): 132-133$.

71. Hyslop, J. A. 1927. A monthly survey report form. J. Econ. Entomol. 20 (5):717-725. Illus.

72. Illinois Cooperative Extension Service. 1965. Insect control for field crops. Ill. Agr. Ext. Serv. Circ. 899. 7 p. Illus.

73. JUDD, W. W. 1970. Insects associated with flowering wild carrot, Daucus carota L., in southern Ontario. Proc. Entomol. Soc. Ont. 1969. 100:176-181. Refs.

74. Kerth, D. L., and W. Gary. 1974. Nebraska pilot pest management project on insects and weeds in corn. Proc. N. Cent. Br. Entomol. Soc. Amer. 29:46-47. Illus. cooperators in south central Nebraska. Proc. N. Cent. Br. Entomol. Soc. Amer. 30:65-67. Illus.

76. King, D. R., J. A. Harding, and B. C. Langley. 1961. Peanut insects in Texas. Tex. Agr. Exp. Sta. Misc. Publ. 550. 14 p. Illus. Refs.

77. KIRK, V. M. 1973. Biology of a ground beetle, Harpalus erraticus. Proc. N. Cent. Br. Entomol. Soc. Amer. 28:208

78. 1973. Biology of a ground beetle, Harpalus pensylvanicus. Ann. Entomol. Soc. Amer. 66 (3):513518. Illus. Refs.

79. 1974. Biology of a ground beetle, Harpalus erraticus. Ann. Entomol. Soc. Amer. 67 (1) :24-28. Illus. Refs.

80. . 1975. Concentration of rainwater by corn plants makes site suitable for oviposition by corn rootworms. Proc. N. Cent. Br. Entomol. Soc. Amer. 30:83.

81. 1975. Suitable oviposition site for corn rootworms (Coleoptera, Chrysomelidae) resulting from concentration of rainwater by corn plant. Agr. Meteorol. 15:113-116. Illus. Refs.

82. Kogan, M. 1974. Insect pests in soybeans. Pages 124133 in Proceedings of the workshop on soybeans for tropical and subtropical conditions. University of Illinois, Urbana-Champaign. (INTSOY Publ. Ser. 2). Illus.

83. Krysan, J. L., T. Branson, and P. L. Guss. 1974. Developments in large scale rearing of corn rootworms. I. Larval restrictions. Proc. N. Cent. Br. Entomol. Soc. Amer. 29:195.

84. lipolysis in an insect egg: Observations in vitro. Biochim. Biophys. Acta 296:466-470. Illus. Refs.

85. LASTER, M. L. 1974. Increasing natural enemy resources through crop rotation and strip cropping. Pages 137-149 in F. G. Maxwell and F. A. Harris, eds., Proceedings of the summer institute on biological control of plant insects and diseases. University of Mississippi Press, Jackson. Illus. Refs.

86. LAwSON, F. R. 1969. The relation of insect control to increased food production. Proc. Tall Timbers Conf. Ecol. Contr. Animal Habitat Manage. 1:145-173. Illus. Refs.

87. Leggett, J. E., and W. H. Cross. 1976. Response of boll weevils and other insects to grandlure exposed in two basic types of traps. J. Econ. Entomol. 69(1):6-8. Illus. Refs.

88. Lieberman, F. V., F. F. Dicke, and D. A. Hills. 1961 Some insect pests of important seed crops. U. S. Dep. Agr. Yearb. Agr. 1961:251-258.

89. Lincoln, C., and F. D. Miner. 1945. Insect pests of grain, hay, and pasture crops. Ark. Agr. Exp. Sta. Ext. Serv. Circ. 437. 19 p. Illus.

90. Lockwood, S. 1938. Field entomology. Calif. Dep. Agr. Bull. 27 (6) :656-661. Illus.

91. LOVETT, O. L. 1975. Wisconsin corn rootworm surveys. Proc. N. Cent. Br. Entomol. Soc. Amer. 30:30-36. Illus. Refs. Maps.

92. Luckmann, W. H., H. C. Chiang, E. E. Ortman, and M. P. NichoLs. 1974. A bibliography of the northern corn rootworm, Diabrotica longicornis (Say) and the western corn rootworm, Diabrotica virgifera LeConte (Coleoptera:Chrysomelidae). Ill. Natur. Hist. Surv. Biol. Notes 90.15 p. Illus.

93. and G. C. DECKER. 1960. A 5-year report on observations in the Japanese beetle control area at Sheldon, Illinois. J. Econ. Entomol. 53 (5) :821-827. Illus. Refs. 
94. and C D. J TSAR. 1975. Corn rootworm pest mallage ment in canning sweet corn. Ill. Natur. Hist. Surv Circ. 54. 10 p. Illus. Refs.

95. Ludwig, K. A., and R. E. Hill. 1975. Comparison of gut contents of adult western and northern corn rootworms in northeast Nebraska. Environ. Entomol. 4 (3) :435-438. Illus. Refs.

96. Luginbill, P. 1918. The southern corn rootworm and farm practices to control it. U.S. Dep. Agr. Farmers' Bull. 950. Il p. Hllus. Maps.

97. LuginbilL, P., JR. 1969. Developing resistant plantsthe ideal method of controlling insects. U.S. Dep. Agr. Prod. Res. Rep. 111.14 p. Illus.

98. McBride, D. K. 1972. North Dakota insect control guide for safe use of pesticides. N. Dak. Coop. Ext. Serv. 68 p. Illus.

99. MicColloch, J. W., and G. A. DeAn. 1929. Insects injurious to corn. Kans. State Bd. Agr. Rep. 48 (191): 193-236. Illus. Refs.

100. MaCNAY, C. G. 1952. Summary of important insect infestations, occurrences, and damage in Canada in 1952. Entomol. Soc. Ont. Annu. Rep. 83:66-94.

101. Madariaga, A. 1919. Plagas y enfermedades del maiz (Pests and diseases of corn). Rer. Agr. (Mexico) $4(9-10): 449-455$. Illus.

102. Marlatr, C. L. 1905. The annual loss occasioned by destructive insects in the United States. U.S. Dep. Agr. Yearb. Agr. 1904:461-474. Illus.

103. MaYo, Z. B. 1975. A five-year comparison of insecticides applied to control larvae of western and north ern corn rootworms. Nebr. Agr. Exp. Sta. SB 535 15 p. Illus. Refs.

104. ___ 1976. Emergency postplanting applications of insecticides to control larvae of the western and northern corn rootworm in Nebraska. J. Econ. Entomol. 69 (5):600-602. Illus. Refs.

105. Metcalf, R. L. 1975. Choosing insecticides for use in pest management programs. Proc. N. Cent. Br. Entomol. Soc. Amer. 30:87. Illus. Refs.

106. ___ and J. R. SANBORN. 1975. Pesticides and en vironmental quality in Illinois. Ill. Natur. Hist. Sury Bull. 31 (9) :381-436. Illus. Refs.

107. Metcalf, Z. P. 1931. The corn root worm. N. C Agr. Exp. Sta. Annu. Rep. 54:107.

108. Minм, J. A., and H. C. Chinag. 1971. The life cycle of free living mites and their feeding potential on corn rootworms (Mesostigmata:Laelaptidae). Proc. N. Cent. Br. Entomol. Soc. Amer. 26 (1-2) :89.

109

1974. Temperature effects on corn rootworm oviposition. Proc. N. Cent. Br. Entomol. Soc. Amer. 29:135-138. Illus. Refs.

110. and 1975. Hatching of northern corn rootworm eggs exposed to saline solutions. Proc. N. Cent. Br. Entomol, Soc. Amer. 30:83.

111. ture relationships of developing corn rootworm eggs. Proc. N. Cent. Br. Entomol. Soc. Amer. 29:141-143. Illus. Refs.

112. Missouri Agricultural Experiment Station. I957. Corn insect studies. Mo. Agr. Exp. Sta. Bull. 683: $16-18$

113. Montgonery, B. E., and J. M. Amos. 1941. Contributions to a list of the Coleoptera of the Clark County State Forest. Proc. Indiana Acad. Sci. 50: 251-258.

114. Musick, G. J. 1971. Resistance of corn to northern corn rootworm. Ohio Agr. Res. Devel. Center Res Summ. 55:23.

115. 1973. New corn rootworm to invade Ohio. Pestic. Inst. News. $26(4): 115-120$. Illus. Refs. Maps.

116. __ 1974. Control of northern corn rootworm with liquid fertilizer-insecticide combination. Proc N. Cent. Br. Entomol. Soc. Amer. 29:191.

117. 1974. Efficacy of liquid starter fertilizerinsecticide combinations for control of resistant northern corn rootworm larvae. J. Econ. Entomol. 67 (5) 668-670. Illus. Refs.

118. 1975. Best corn rootworm control with banded insecticides. Ohio Rep. Res. Devel. $60(1)$ : $3-5$. Illus.

$119 . \quad$ and O. K. HEDDEN. 1971. Evaluation of experimental and recommended insecticides for control of northern corn rootworm. Ohio Agr. Res. Devel. Center Res. Summ. 55:23.

120. Nebraska Agricultural Experiment Station. 1888. Report of the Entomologist. Nebr. State Bd. Agr. Annu. Rep. 1888:84-130. Illus. Refs.

121. NeISWANDER, C. R. 1931. The sources of American corn insects. Ohio Agr. Exp. Sta. Bull. 473. 98 p. Illus. Refs. Maps.

129. Ohio State University Cooperative Extension SerVICE. 1972. Insect pests of field crops. Ohio State Univ. Coop. Ext. Serv. Bull. 545. 20 p. Illus. Maps.

123. Ontario Ministry of Agriculture and Food. 1974. 1974 field crop recommendations. Ont. Min. Agr. Food Publ. 296. 61 p. Illus. Maps.

124. Orlando, A. 1942. Observações dos hábitos de "Heliothis obsoleta (Fabr.)" como praga das espigas de milho, e a eliminação dos estilos-estigmas como processo de combate (Lep. Noct.) (Observations on the behavior of "Heliothis obsoleta (Fabr.)" as a pest of corn ears and the removal of the silks as a control measure). Arq. Inst. Biol. São Paulo 13 (18) : 191-207.

125. Ortifan, E. E., and T. F. Branson, 1976. Growth pouches for studies of host plant resistance to larvae of corn rootworms. J. Econ. Entomol. 69 (3):380-382. Illus. Refs.

126. and E. D. Gerloff, 1974. Techniques, accomplishments, and future potential of host plant resistance to Diabrotica. Pages $344-358$ in F. G. Maxwell and F. A. Harris, eds., Proceedings of the summer institute on biological control of plant insects and diseases. University of Mississippi Press, Jackson. Illus. Refs.

127. Osborn, H. 1894. Corn insects. Their injuries and how to treat them. Iowa Agr. Exp. Sta. Bull. 24:9911005. Illus.

129. Osiun, J. V. 1958. Insects and other arthropods of economic importance in Indiana in 1957. Proc. Indiana Acad. Sci. 67:150-154.

129. 1960. Insects and other arthropods of economic importance in Indiana in 1959. Proc. Indiana Acad. Sci. 69:167-174.

130. Owens, J. C., D. C. Peters, and A. R. Hallauer. 1974. Corn rootworm tolerance in maize. Environ. Entomol. 3 (5):767-772. Illus. Refs.

131. J. F. Witkowski, J. J. Tollefson, R. R. Rogers, and D. C. Peters. 1974. Greenhouse evaluation of soil insecticides for western corn rootworm control. J. Econ. Entomol. $67(6): 772-774$. Illus. Refs. 
132. PAinter, R. H. 1968. Crops that resist insects provide a way to increase world food supply. Kans. Agr. Exp. Sta. Bull. 520. 22 p. Illus. Maps.

133. Palmer, D. F., M. B. Windels, and H. C. Chiang. 1976. Changes in specific gravity of developing western corn rootworm eggs. Environ. Entomol. 5(4): 621-622. Illus. Refs.

134. Proigo, L. P. 1972. Economic levels of insect pests. Iowa State Univ. Coop. Ext. Serv. EC-713e. 4 p. Illus. Refs.

\#135. Peric, I. 1974. Possibilities of using a synergist in controlling harmful insects (in Serbo-Croatian). Agron. Glas. $36(9-12): 577-584$.

136 Pimentel, D., and A. G. Wheeler. 1973. Species and diversity of arthropods in the alfalfa community. Environ. Entomol. 2(4):659-668. Illus. Refs.

137. Popenoe, E. A. 1876. A list of Kansas Coleoptera. Kans. Acad. Sci. 5:21-40.

138. Pruess, K. P. 1974. Tarnished and alfalfa plant bugs in alfalfa: Population suppression with ULV malathion. J. Econ. Entomol. 67 (4):525-528. Illus. Refs.

139. — J. F. Witkowski, and E. S. Raun. 1974. Population suppression of western corn rootworm by adult control with ULV malathion. J. Econ. Entomol. 67 (5) :651-655. Illus. Refs.

140. Rasmussen, D. E., and H. C. Chiang. 1973. The effects of various artificial infestation levels of corn rootworm on field corn. Proc. N. Cent. Br. Entomol. Soc. Amer. 28:207.

141. Rogers, R. R., and J. C. Owens. 1974. Relationship of carbofuran treatment to agronomic traits in maize. J. Econ. Entomol. 67 (4):557-558. Illus. Refs.

142. _ J. J. Tollefson, and J. F. WiTKOWSKI. 1975. Evaluation of commercial corn hybrids for tolerance to corn rootworms. Environ. Entomol. $4(6)$ : 920-922. Illus. Refs.

143. W. A. Russell, and J. C. Owens. 1976. Evaluation of a vertical-pull technique in population improvement of maize for corn rootworm tolerance. Crop Sci. 16:591-594. Illus. Refs.

144. and

1976. Relationship of corn rootworm tolerance to yield in the BSSS maize population. Iowa State J. Res. 51 (1):125129. Illus. Refs.

145. Roussel, J. S., F. S. SABA, H. T. Reynolds, A. J. Forgash, J. R. Brazzel, C. C. Burkhardt, and W. J. Collins. 1972. Standard methods for detection of insecticide resistance in Diabrotica and Hypera beetles. Bull. Entomol. Soc. Amer. 18 (4):179-182. Illus. Refs.

146. Ruesink, W. G. 1975. Estimating time-varying survival of arthropod life stages from population density. Ecology $56(\mathrm{I}): 244-247$. Illus. Refs.

147. RUPPEL, R. F. 1975. Dispersal of western corn rootworm, Diabrotica virgifera Le Conte, in Michigan (Coleoptera:Chrysomelidae). J. Kans. Entomol. Soc. 48 (3) :291-296. Refs. Maps.

148. a and R. L. JANES. 1970. Insect control in forages, field corn and small grains. Mich. State Univ. Coop. Ext. Serv. Ext. Bull. 672. 7 p. Illus.

149. and D. C. KAISER. 1973. Corn rootworms in Michigan. Mich. Agr. Exp. Sta. Res. Rep. 206. 7 p. Illus. Refs. Maps.

150. Schalk, J. M., and R. H. Ratcliffe. 1976. Evaluation of ARS program on alternative methods of insect control: Host plant resistance to insects. Bull. Entomol. Soc. Amer. 22 (I) :7-10. Illus. Refs.
151. Scheibner, R. A., W. W. Gregory, and H. G. Raney. 1972. 1972 insecticide recommendations for field corn, small grains, grain sorghum, and bluegrass. Ky. Coop. Ext. Serv, Misc. Publ. 278-I. 6 p.

152. SECHRIEST, R. E. 1975. Rootworm beetle control doubles corn protection. Agrichem. Age. 18(5):12. Illus.

153. SEFIR, E. 1963. Catalogo dos insectos que atacam as plantas cultivadas da Amazonia (Catalog of insects that attack crops in the Amazon). Bol. Tec. Inst. Agron. Norte (Brazil) 43:23-53.

154. Sellers, L. G., and P. A. Damm. 1974. Insecticide residues in ground beetles and soil. Proc. N. Cent. Br. Entomol. Soc. Amer. 29:145-146.

155. $\longrightarrow$ and 1975. Chlorinated hydrocarbon insecticide residues in ground beetles (Harpalus pensylvanicus) and Iowa soil. Bull. Environ. Contam. Toxicol. 13 (2) :218-222. Illus. Refs.

156. Shaw, J. T., R. O. Ellis, and W. H. LuckmanN. 1976. Apparatus and procedure for extracting corn rootworm eggs from soil. Ill. Natur. Hist. Surv. Biol. Notes 96. 4 p. Illus. Refs.

157. Sмитн, J. B. 1893. Farm practice and fertilizer as insecticides. Insect Life $6(2): 93-97$.

158. Smith, R. C., E. G. Kelly, G. A. Dean, H. R. Bryson, and R. L. Parker. 1943. Common insects of Kansas. Kans. State Bd. Agr. Rep. 62 (255):117-414. Illus.

159. South Dakota Agricultural Experiment Station. 1955. Crop insects. S. Dak. Agr. Exp. Sta. Annu. Rep. 68:112-113. Maps.

160. South Dakota State University. 1973. 1973 corn rootworm research and extension activities. South Dakota State University Corn Rootworm and Extension Activities. 2 p. Illus.

161. Staetz, C. A., H. J. Ball, and S. D. Carlson. 1976. Antennal morphology of Diabrotica virgifera adults (Coleoptera:Chrysomelidae). Ann. Entomol. Soc. Amer. 69 (4):695-698. Illus. Refs.

162. Stockdale, H. J., and J. R. DeWitt. 1976. Corn rootworms and their control. Iowa Coop. Ext. Serv. PM-670. 3 p. Illus.

163. Suwantaradon, K., S. A. Eberhart, J. J. Mock, J. C. OWENS, and W. D. Guthrie. 1975. Index selection for several agronomic traits in the BSSS2 maize population. Crop Sci. 15 (6):827-833. Illus. Refs.

164. SWENK, M. H. 1908. The principal insects injurious to agriculture during 1906-07. Nebr. State Bd. Agr. Annu. Rep. 1906-1907:287-306. Illus. Refs.

165. TAYloR, C. R. 1975. The economics of control of northern and western corn rootworms in Illinois. Ill. Agr. Econ. 15 (2) :11-13. Illus. Refs.

166. Titus, E. S. G., and F. C. Pratt. 1904. Catalogue of the exhibit of economic entomology at the Louisiana Purchase Exposition, St. Louis, Mo., 1904. U. S. Dep. Agr. Div. Entomol. Bull. (N.S.) 47. 155 p. Refs.

167. Tollefson, J. J., J. C. Owens, and J. F. Wilkowski. 1975. Influence of sticky trap color and size on catch of corn rootworm adults. Proc. N. Cent. Br. Entomol. Soc. Amer. 30:83.

168. Townsend, C. H. T. 1891. Notes of interest. Insect Life $4(1-2): 26-27$.

169. TURnipseed, S. G., and M. Kogan. 1976. Soybean entomology. Annu. Rev. Entomol. 21:247-282. Illus. Refs.

170. TyLer, B. M. J., and C. R. Ellis. 1975. Adult emergence, oviposition and lodging damage of northern 
corn rootworm (Coleoptera:Chrysomelidae) under three tillage systems. Proc. Entomol. Soc. Ont. 1974. 105:86-89. Illus. Refs.

171. U. S. Department of Agriculture. 1916. Report of the entomologist. U. S. Dep. Agr. Bur. Entomol. Rep. Entomol. 1916. $24 \mathrm{p}$.

172. 1965. Losses in agriculture. U. S. Dep. Agr. Agr. Handb. 291:40-54. Illus.

1969. Suggested guide for the use of insecticides to control insects affecting crops, livestock, households, stored products, forests, and forest products-1968. U. S. Dep. Agr. Agr. Handb. 331 (Add. No. 2). 8 p.

174. VAN WOeRKom, G. 1975. A comparison of LD-50 values for northern corn rootworm adults in high and low aldrin use areas in Indiana. Proc. N. Cent. Br. Entomol. Soc. Amer. 30:82.

175. WeBster, F. M. 1893. Insect foes of American cereal grains, with measures for their prevention or destruction. Insect Life $6(2): 146-157$. Illus. Refs.

1895. On the probable origin, development and diffusion of North American species of the genus Diabrotica. J. N. Y. Entomol. Soc. 3 (4):158-166.

177. 1896. The probable origin and diffusion of North American species of the genus DiabroticaII. J. N. Y. Entomol. Soc. $4(2): 67-68$.

178. WeBster, J. A. 1975. Association of plant hairs and insect resistance: An annotated bibliography. U. S. Dep. Agr. Misc. Publ. 1297. 18 p. Illus. Refs.

179. WeIsER, J. 1973. Corn rootworm control: One key to better yields in 1973. Dairy Herd Manage. $10(1)$ : $46-48$, 50. Illus. Maps.

180. Wiскнам, H. F. 1897. The Coleoptera of Canada. IX. The Chrysomelidae of Ontario and Quebec. (Continued). Tribe IX. Galerucini. Can. Entomol. $29(1): 7-12$. Illus.

181. Mincox. J. 1. 1954. Leaf beetles of Ohio (Chrysomelidae:Coleoptera). Ohio Biol. Surv. Bull. 43:353506. Illus. Refs. Maps.

182. Wilde, G., and H. Reissing. 1971. Differential feeding by the western corn rootworm on silks of various corn sources. Proc. N. Cent. Br. Entomol. Soc. Amer. $26(1-2): 88$.

183. Wille, J. E. 1946. Experimentos con los neuvos insecticidas DDT y Gammexane ejecutados en las Estación Experimental Agricola de la Molina hasta fines de Mayo de 1946 (Experiments with the new insecticides DDT and Gammexane carried out at the La Molina Agricultural Experiment Station up to the end of May, 1946). La Molina Estac. Exp. Agr. Bol. 29. 33 p. Illus. Refs.

184. Wilson, R. L., and D. C. Peters. 1973. Plant introductions of Zea mays as sources of corn rootworm tolerance. J. Econ. Entomol. 66 (1):101-104. Illus. Refs.

185. Witkowski, J. F., J. C. Owens, and J. J. Tollefson. 1975. Diel activity and vertical flight distribution of adult western corn rootworms in Iowa cornfields. J. Econ. Entomol. 68 (3) : 351-352. Illus. Refs.

186. Woolsey, G. 1974. A county agent's views on pest management. Proc. N. Cent. Br. Entomol. Soc. Amer. 29:39-40.

187. Wresselt, H. B. 1955. Insects attacking corn in eastern Canada. Can. Dep. Agr. Publ. 945. 8 p. Illus.

188 1971. A survey of insects infesting vegetable crops in southwestern Ontario, 1969. Proc. Entomol. Soc. Ont. 1970. 101:13-23. Illus. Refs.

\section{ADDENDUM}

189. Gallum, R. L., K. J. Starks, and W. D. Guthrie. 1975. Plant resistance to insects attacking cereals. Annu. Rev. Entomol. 20:337-357. Illus. Refs.

190. Gregory, W. W., and G. J. Musick. 1976. Insect management in reduced tillage systems. Bull. Entomol. Soc. Amer. $22(3): 302-301$. Kefs.

19I. Kantack, B. H. 1976. Corn rootworms: Control of larvae via adults not a wise practice. Crops Soils Mag. $29(2): 11-12$. Illus.

192. Moovey, E., and F. T. Turpin. 1976. Rowsim, a Gasp IV based rootworm simulator. Indiana Agr. Exp. Sta. Res. Bull. 938. 24 p. Illus. Refs.

193. MuMa, M. H. 1946. Insects injurious to corn in Nebraska. Nebr. Agr. Ext. Serv. Ext. Circ. 1537. 20 p.

\section{LISTING OF REFERENCES BY ROOTWORM SPECIES}

I. Northern corn rootworm, Diabrotica longicornis (Say)

$2,5,6,9,13,16,17,23,24,25,27,28,29,30,32,33,35,36$, $37,38,39,42,43,44,48,49,50,51,54,55,58,59,60,62,63$, $65,66,68,69,70,71,72,73,74,79,81,82,85,86,88,89,91$, $92,93,94,95,96,99,100,101,102,103,104,106,107,108$, $109,110,112,113,114,116,117,118,119,120,121,123,126$, $127,128,129,130,135,136,137,143,144,146,148,149,150$, $152,156,157,158,159,162,163,164,165,166,169,170,172$, $174,175,176,177,179,180,181,184,187,188,189,190,192$, 193.

II. Western corn rootworm, Diabrotica virgifera LeConte

$6,11,20,21,22,23,24,26,27,29,30,32,34,40,45,55,56$, $57,61,62,63,64,66,67,74,78,79,81,82,8 \frac{1}{4}, 91,92,94,95$, $103,104,106,108,109,111,115,125,126,130,131,133,138$, $139,143,144,147,149,152,154,155,156,161,162,163,165$, $169,171,172,178,179,182,184,185,186,189,190,192,193$.

III. Diabrotica spp.

$1,3,4,7,8,10,12,14,15,18,19,31,41,46,47,52,53,75$, $76,77,80,83,87,90,97,98,105,122,124,133,134,140$, $141,142,145,151,153,160,167,168,173,183,191$.

\section{PERIODICAL ABBREVIATIONS}

Agr. Meteorol.-Agricultural Meteorology.

Agrichem. Age-Agrichemical Age.

Agron. Glas.-Agronomski Glasnik.

Ann. Entomol. Soc. Amer.-Annals of the Entomological Society of America.

Ann. Soc. Entomol. Quebec-Annales de la Societe Entomologique de Quebec.

Annu. Rev. Entomol.-Annual Review of Entomology.

Ariz. Agr. Exp. Sta., Ariz. Coop. Ext. Serv. Folder-Arizona Agricultural Experiment Station and Arizona Cooperative Extension Service Folder.

Ark. Agr. Exp. Sta. Ext. Serv. Circ-Arkansas Agricultural Experiment Station Extension Sexvice Circular.

Arq. Inst. Biol. São Paulo-Arquivos do Instituto Biologico São Paulo.

Biochim. Biophys. Acta-Biochimica et Biophysica Acta.

Bol. Tec. Inst. Agron. Norte (Brazil)-Boletin Tecnico do Insti. tuto Agronomico do Norte (Brazil)

Bull. Entomol. Soc. Amer.-Bulletin of the Entomological Society of America. 
Bull. Environ. Contam. Toxicol-Bulletin of Environmental Contamination and Toxicology.

CIAT Ser. Semin--CIAT (Centro International de Agricultura Tropical) Serie Seminario.

Calif. Dep. Agr. Bull.-California Department of Agriculture Bulletin.

Can. Dep. Agr. Publ-Canada Department of Agriculture Publication.

Can. Entomol-Canadian Eniomologist.

Can. J. Plant Sci--Canadian Journal of Plant Science.

Crop Sci.-Crop Science.

Crops Soils Mag,-Crops and Soils Magazine.

Dairy Herd Manage.-Dairy Herd Management.

El Salvador Min. Agr. Ganad. Bol. Tec--El!alvador Ministerio de Agricultura y Ganaderia Boletin Tecnico.

Entomol. Exp. Appl.-Entomologia Experimentalis et Applicata.

Entomol. Soc. Ont. Annu. Rep.-Entomological Society of Ontario Annual Report.

Environ. Entomol.-Environmental Entomology.

Folia Entomol. Mex,-Folia Entomologica Mexicana.

111. Agr. Econ,-Illinois Agricultural Economics.

Ill. Agr. Exp. Sta. Bull.-Illinois Agricultural Experiment Station Bulletin.

IIl. Agr. Ext. Serv. Circ-Illinois Agricultural Extension Service Circular.

III. Coop. Ext. Serv. Ill. Coll. Agr. Ill. Natur. Hist. Surv,-Illinois Cooperative Extension Service, Illinois College of Agricul. ture, Illinois Natural History Survey.

III. Natur. Hist. Surv. Biol. Notes-Illinois Natural History Survey Biological Notes.

III. Natur. Hist. Surv. Bull.-Illinois Natural History Survey Bulletin.

Ill. Natur. Hist. Surv. Circ--Illinois Natural History Survey Circular.

Indiana Agr. Exp. Sta. Res. Bull.-Indiana Agricultural Experiment Station Research Bulletin.

Indiana Dep. Geol. Natur. Res. Bull-Indiana Department of Geology and Natural Resources Bulletin

Iowa Agr. Exp. Sta. Bull.-Iowa Agricultural Experiment Station Bulletin.

Iowa Coop. Ext. Serv.-Iowa Cooperative Extension Service.

Iowa State Coll. J. Sci.-Iowa State College Journal of Science.

Iowa State J. Res.-Iowa State Journal of Research.

Iowa State Univ. Coop. Ext. Serv.-Iowa State University Cooperative Exiension Service.

J. Econ. Entomol--Journal of Economic Entomology.

J. Kans. Entomol. Soc.-Journal of the Kansas Entomological Society.

J. N. Y. Entomol. Soc-Journal of the New York Entomological Society.

Kans. Acad. Sci.-Kansas Academy of Science.

Kans. Agr. Exp. Sta. Bull.-Kansas Agricultural Experiment Station Bulletin.

Kans. State Bd. Agr. Rep.-Kansas State Board of Agriculture Report.

Ky. Agr. Exp. Sta. Bull--Kentucky Agricultural Experiment Station Bulletin.

Ky. Coop. Ext. Serv. Misc. Publ.-Kentucky Cooperative Extension Service Miscellaneous Publication.

La Molina Estac. Exp. Agr. Biol.-La Molina Estacion Experimental Agricola Boletin.

Mich. Agr. Exp. Sta. Res. Rep.-Michigan Agricultural Experiment Station Research Report.

Mich. State Univ, Coop. Ext. Serv. Ext. Bull.-Michigan State University Cooperative Extension Service Extension Bulletin

Mo. Agr. Exp. Sta. Bull.-Missouri Agricultural Experiment Sta. tion Bulletin

Mo. Agr. Exp. Sta. Res. Bull.-Missouri Agricultural Experiment Station Research Bulletin.

Mo. Coop. Ext. Serv. Handb.-Missouri Cooperative Extension Service Handbook.

N. C. Agr. Exp. Sta. Annu. Rep.-North Carolina Agricultural Experiment Station Annual Report.
N. Y. (Cornell) Coll. Agr. Misc. Bull.-New York (Cornell) College of Agriculture Miscellaneous Bulletin.

N. Dak. Coop. Ext: Serv.-North Dakota Cooperative Extension Service.

Natur. Can.-Nature Canada (Le Naturaliste Canadien).

Nebr. Agr. Exp. Sta. Annu. Rep.-Nebraska Agricultural Experiment Station Annual Report.

Nebr. Agr. Exp. Sta. SB-Nebraska Agricultural Experiment Station SB.

Nebr. Agr. Ext. Serv. Ext. Circ--Nebraska Agricultural Extension Service Extension Circular.

Nebr. State Bd. Agr. Annu. Rep.-Nebraska State Board of Agriculture Annual Report.

Ohio Agr. Exp. Sta. Bull.-Ohio Agricultural Experiment Station Bulle.in.

Ohio Agr. Res. Devel. Center Res. Summ.-Ohio Agricultural Research and Development Center Research Summary.

Ohio Biol. Surv. Bull.-Ohio Biological Survey Bulletin.

Ohio Coop. Ext. Serv. Bull-Ohio Cooperative Extension Service Bulletin.

Ohio J. Sci--Ohio Journal of Science.

Ohio Rep. Res. Devel.-Ohio Report on Research and Development.

Ohio State Univ. Coop. Ext. Serv,-Ohio State University Cooperative Extension Service.

Ohio State Univ. Coop. Ext. Serv. Bull-OOhio State University Cooperative Exıension : ervice Bulletin.

Ont. Min. Agr. Food Publ.-Ontario Ministry of Agriculture and Food Publication.

Pestic. Inst. News-The Pesticide Institute News.

Plants Gard.-Plants and Gardens.

Proc. Annu. Hybrid Corn Ind. Res. Conf--Proceedings of the Annual Hybrid Corn Industry Research Confesence (American Seed Trade Association).

Proc. Entomol. Soc. Ont,-Proceedings of the Entomological Society of Ontario.

Proc. Indiana Acad. Sci.-Proceedings of the Indiana Academy of Science.

Proc. N. Cent. Br. Entomol, Soc. Amer-Proceedings of the North Central Branch of the Entomological Society of America.

Proc. Tall Timbers Conf. Ecol. Animal Contr. Habitat Manage.Proceedings of the Tall Timbers Conference on Ecological Animal Contiol by Habitat Management.

Rev. Agr. (Mexico)-Revista de Agricultura (Mexico) .

Rev. Peru. Entomol. Agr,-Revista Peruana de Entomologia Agricole.

Riv. Agr. Subtrop. Trop.-Rivista de Agricolture, Subtropical et Tropical.

S. C. Agr. Exp. Sta. Bull-South Carolina Agricultural Experiment Station Bulletin.

S. Dak. Agr. Exp. Sta. Annu. Rep,-South Dakota Agricultural Experiment Station Annual Report.

Tex. Agr. Exp. Sta. Misc. Publ.-Texas Agricultural Experiment Station Miscellaneous Publication.

U. S. Dep. Agr. Agr. Handb.-United States Department of Agriculture, Agriculture Handbook.

U. S. Dep. Agr. Agr. Res. ¿erv. NC-United States Department of Agriculture, Agricultural Research Service NC.

U. S. Dep. Agr. Bur. Entomol. Rep. Entomol.-United States Department of Agriculture, Bureau of Entomology, Report of the Entomologist.

U. S. Dep. Agr. Div. Entomol. Bull--United States Department of Agriculture, Division of Entomology Bulletin.

U. S. Dep. Agr. Farmers' Bull.-United States Department of Ag. riculture Farmers' Bulletin.

U. S. Dep. Agr. Misc. Publ--United States Department of Agriculture Miscellaneous Publication.

U. S. Dep. Agr. Prod. Res. Rep.-United States Department of Agriculture Product Research Report.

U. S. Dep. Agr. Yearb. Agr.-United States Department of Agriculture, Yearbook of Agriculture.

Va. J. Sci-Virginia Journal of Science.

W. Va. Agr. Exp. Sta. Bull.-West Virginia Agricultural Experiment Station Bulletin. 






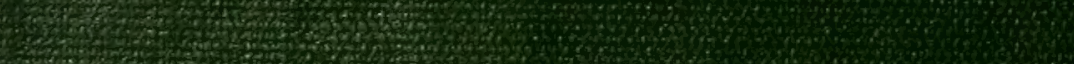

